
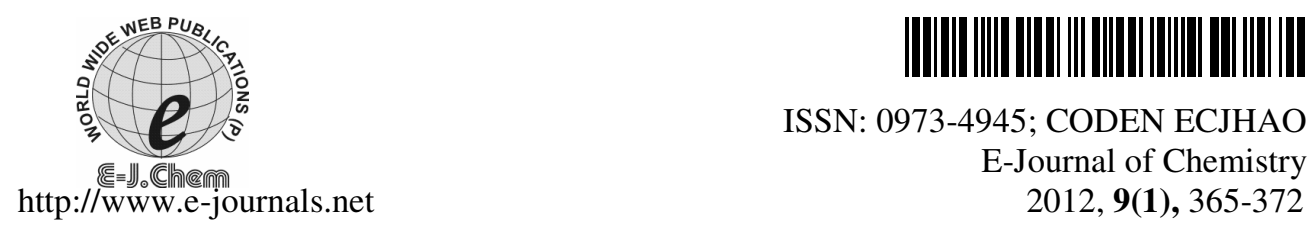

ISSN: 0973-4945; CODEN ECJHAO

E-Journal of Chemistry 2012, 9(1), 365-372

\title{
Transition Metal Complexes of Isonicotinoyl- -hydrazone-4-diphenylaminobenzaldehyde: Synthesis, Characterization and Antimicrobial Studies
}

\author{
L. MITU*, M. ILIS ${ }^{\S}$, N. RAMAN ${ }^{\#}$, M. IMRAN ${ }^{\llbracket}$ and S. RAVICHANDRAN \\ *Department of Physics and Chemistry, University of Piteşti, Pitesti-110040, Romania \\ ${ }^{\S}$ Inorganic Chemistry Department, University of Bucharest \\ 23 Dumbrava Roşie Street, 020464, Bucharest, Romania \\ "Department of Chemistry, College VHNSN, Virudhunagar - 626001, India \\ II Institute of Chemistry, University of Punjab, Lahore - 54590, Pakistan \\ Vel Tech Dr.RR \&Dr. SR Technical University \\ Avadi, Chennai-600 062, India \\ ktm7ro@yahoo.com
}

Received 11 November 2010, Accepted 20 December 2011

\begin{abstract}
A series of complexes of $\mathrm{Cu}(\mathrm{II}), \mathrm{Ni}(\mathrm{II}), \mathrm{Co}(\mathrm{II}), \mathrm{Mn}(\mathrm{II})$ and $\mathrm{Cd}(\mathrm{II})$ with isonicotinoylhydrazone-4-diphenylaminobenzaldehyde (INHDAB) has been reported. The complexes have been characterized by analytical data, IR, UV-Vis, NMR spectra, magnetic susceptibility values, thermal analysis and for the $\mathrm{Cu}$ (II) complex the ESR spectrum has been registered. The biological activity of these complexes were investigated against Staphylococcus aureus, Escherichia coli, Pseudomonas aeruginosa, Salmonella enteritidis, Shigella flexneri bacteria. The INHDAB ligand is coordinate at the metallic ions by oxygen amide $(\mathrm{O}=\mathrm{C})$ and the azomethine nitrogen.
\end{abstract}

Keywords: Template synthesis, Isonicotinoylhydrazone, Complexes, Antibacterial activity

\section{Introduction}

The heterocyclic chemistry offers the results of the researches show a lot of bioactive substances. The parameters of the chemical structure, the physical and electronical characteristics of the molecule are determined factors in the manifestation of the bioactivity ${ }^{1-3}$. Hydrazones and Schiff bases were the subject of many interesting studies due to their important applications in much synthetic areas especially in indicators-chemistry. Hydrazones are being used extensively in detection and quantitative determination of several metals, for the preparation of compounds having diverse structures, analytical chemistry for the identification and isolation of carbonyl compounds ${ }^{4}$. However, the most valuable property of hydrazones is perhaps their great physiological activity. It is well known that the 
hydrazone group provides a wide range of application in biological and pharmaceutical fields. Therefore, a number of hydrazide-hydrazone derivatives have been claimed to possess interesting antibacterial-antifungal, anticonvulsant, antiinflammatory, antimalarial and antituberculosis activities ${ }^{5-12}$. In the continuation of our earlier studies on the complexes with the ligands from the aroylhydrazone class ${ }^{13,14}$ we report here the synthesis and characterization of the complexes of $\mathrm{Cu}(\mathrm{II}), \mathrm{Ni}(\mathrm{II}), \mathrm{Co}(\mathrm{II}), \mathrm{Mn}(\mathrm{II}), \mathrm{Cd}(\mathrm{II})$ with the isonicotinoylhydrazone-4-diphenylaminobenzaldehyde ligand.

\section{Experimental}

All reagents and solvents used are of the type AR and were used without further purification. The metal content and chlorine was obtained by the literature methods ${ }^{15}$ and carbon, hydrogen and nitrogen were determined with an analyzer CHN-Hewlett Packard 185. The IR spectra were recorded between $4000-400 \mathrm{~cm}^{-1}$ on a BIORAD-FT-IR 135 FTS spectrophotometer in a disc of anhydrous $\mathrm{KBr}$. The electronic spectra in reflection $(300-1100 \mathrm{~nm})$ were obtained on a VSU-2P Zeiss-Jena spectrophotometer using $\mathrm{MgO}$ as a standard. The ESR spectrum for the $\mathrm{Cu}$ (II) complex were registered at room temperature $(293 \mathrm{~K})$ on a microcrystalline powder with an ART 5 spectrophotometer. The magnetic moments were determined by the Faraday method at the room temperature. ${ }^{1} \mathrm{H}$ and ${ }^{13} \mathrm{C}$ NMR spectra were recorded on a device Varian Gemini 300BB in DMSO- $d_{6}$. The molar conductivity of the complexes was measured with a $\mathrm{HACH}$-sens ion 5-conductivitymeter to the solutions in DMF $10^{-3} \mathrm{M}$. The thermic analysis was realized with an MOM-Q-1500 D derivatograph in air with a heating rate of $5^{\circ} \mathrm{C} / \mathrm{min}$. The biological activity of the complexes was studied by the diffusion technic in agar plates using $\mathrm{DMF}$ as solvent at the concentration of $150 \mu \mathrm{g} / \mathrm{mL}$.

\section{Synthesis of ligand (INHDAB)}

A solution of $0.001 \mathrm{~mol}$ of isonicotinoylhydrazine and $0.001 \mathrm{~mol}$ of 4-diphenylaminobenzaldehyde in $75 \mathrm{~mL}\left(\mathrm{MeOH}+\mathrm{C}_{6} \mathrm{H}_{6}\right)$ was refluxed for $4 \mathrm{~h}$ on a water-bath. After the solution was concentrated the precipitate was filtered and recrystallized from ethanol (Figure 1).

\section{Synthesis of complexes}

A methanolic solution of metal chloride $\mathrm{MCl} 2(0.002 \mathrm{~mol} / 25 \mathrm{~mL} \mathrm{MeOH})$ was added to a mixture of isonicotinoylhydrazine $(0.002 \mathrm{~mol} \mathrm{INH} / 40 \mathrm{~mL} \mathrm{MeOH})$ and 4-diphenylaminobenzaldehyde $\left(0.002 \mathrm{~mol} \mathrm{DAB} / 60 \mathrm{~mL} \mathrm{MeOH}+\mathrm{C}_{6} \mathrm{H}_{6}\right)$. The reaction mixture was refluxed on a water-bath for $4 \mathrm{~h}$ after which a part of the solvent was removed by distillation. The precipitated complexes were filtered, washed with methyl alcohol and then with ether and finally dried in vacuum on anhydrous $\mathrm{CaCl}_{2}$.

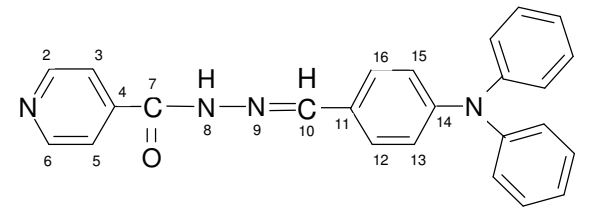

Figure 1. Isonicotinoylhydrazone-4-diphenylaminobenzaldehyde (INHDAB = HL).

\section{Results and Discussion}

The obtained complexes were coloured powders, stable for a long time in the open atmosphere, insoluble in methanol, ethanol, chloroform and acetone; the complex combinations of $\mathrm{Ni}(\mathrm{II}), \mathrm{Co}(\mathrm{II}), \mathrm{Mn}(\mathrm{II})$ are soluble in DMF but the complexes of $\mathrm{Cu}(\mathrm{II})$, $\mathrm{Cd}(\mathrm{II})$ are partly soluble. The analytical data suggest a ratio of 1:1 (metal : ligand) for the 
complexes of $\mathrm{Cu}(\mathrm{II}), \mathrm{Ni}(\mathrm{II}), \mathrm{Cd}(\mathrm{II})$ and of 1:2 for the complexes of $\mathrm{Co}(\mathrm{II}), \mathrm{Mn}(\mathrm{II})$ (Table 1). The presence of lattice water was confirmed by TG analysis. The molar conductivity corresponding for the $\mathrm{Ni}(\mathrm{II}), \mathrm{Co}(\mathrm{II}), \mathrm{Mn}(\mathrm{II})$ complexes present low values and in this way it can be assigned a structural formula of non-electrolyte for these.

Table 1. Analytical and physical data of the complexes.

\begin{tabular}{|c|c|c|c|c|c|c|c|}
\hline \multirow[b]{2}{*}{ Compound } & \multirow{2}{*}{$\begin{array}{l}\text { Colour / } \\
\text { m.p, }{ }^{\circ} \mathrm{C}\end{array}$} & \multicolumn{5}{|c|}{ Found(Calcd.), \% } & \multirow{2}{*}{$\begin{array}{c}\Lambda_{\mathrm{m}}{ }^{*} \\
\Omega^{-1} \mathrm{~cm}^{2} \mathrm{~mol}^{-1}\end{array}$} \\
\hline & & $M$ & $\mathrm{C}$ & $\mathrm{H}$ & $\mathrm{N}$ & $\mathrm{Cl}$ & \\
\hline \multirow{2}{*}{$\begin{array}{l}\text { INHDAB (HL) } \\
\mathrm{C}_{25} \mathrm{H}_{20} \mathrm{~N}_{4} \mathrm{O}\end{array}$} & Yellow / & - & 76.35 & $4 . .89$ & 14.06 & - & - \\
\hline & 209 & & (76.53) & $(5.10)$ & (14.28) & & \\
\hline \multirow{2}{*}[\mathrm{Cu}(\mathrm{HL})\mathrm{Cl}_{2}]{} & $\begin{array}{c}\text { Brown / } \\
248\end{array}$ & $\begin{array}{c}11.83 \\
(12.06)\end{array}$ & $\begin{array}{c}56.76 \\
(56.97)\end{array}$ & $\begin{array}{c}3.57 \\
(3.79)\end{array}$ & $\begin{array}{c}10.40 \\
(10.63)\end{array}$ & $\begin{array}{l}13.26 \\
(13.48)\end{array}$ & - \\
\hline & Orange / & 10.30 & 53.56 & 4.09 & 9.81 & 12.51 & 13.52 \\
\hline \multirow[t]{2}{*}[\mathrm{Ni}(\mathrm{HL})\mathrm{Cl}_{2}]{$\cdot 2 \mathrm{H}_{2} \mathrm{O}$} & 226 & $(10.52)$ & $(53.79)$ & $(4.30)$ & (10.04) & (12.73) & \\
\hline & Brown / & 5.98 & 62.93 & 4.41 & 11.56 & 7.25 & 10.74 \\
\hline \multirow[t]{2}{*}[\mathrm{Co}(\mathrm{HL})_{2}\mathrm{Cl}_{2}]{$\cdot 2 \mathrm{H}_{2} \mathrm{O}$} & 221 & $(6.20)$ & $(63.16)$ & $(4.63)$ & (11.79) & $(7.47)$ & \\
\hline & Light & 5.82 & 65.72 & 4.17 & 12.07 & 7.58 & \\
\hline$\left[\mathrm{Mn}(\mathrm{HL})_{2} \mathrm{Cl}_{2}\right]$ & $\begin{array}{c}\text { Yellow / } \\
>280\end{array}$ & $(6.03)$ & $(65.93)$ & (4.39) & (12.30) & $(7.80)$ & 14.38 \\
\hline$\left[\mathrm{Cd}(\mathrm{HL}) \mathrm{Cl}_{2}\right]$ & $\begin{array}{c}\text { Yellow / } \\
>280\end{array}$ & $\begin{array}{c}19.32 \\
(19.53)\end{array}$ & $\begin{array}{c}51.92 \\
(52.13)\end{array}$ & $\begin{array}{c}3.24 \\
(3.47)\end{array}$ & $\begin{array}{c}9.49 \\
(9.73)\end{array}$ & $\begin{array}{l}12.13 \\
(12.33)\end{array}$ & - \\
\hline
\end{tabular}

\section{Infrared spectra}

The IR spectra analysis gave information about the mode of coordination of the INHDAB ligand to the metallic ions. The characteristic bands are presented in Table 2.

Table 2. Characteristic IR bands $\left(\mathrm{cm}^{-1}\right)$ of the INHDAB ligand and its complexes.

\begin{tabular}{|c|c|c|c|c|c|c|c|c|}
\hline Compound & $\begin{array}{c}v_{\mathrm{OH}} \\
\text { water }\end{array}$ & $v \mathrm{NH}$ & $\begin{array}{c}v \mathrm{C}=\mathrm{O} \\
\text { Amide } \\
\text { I }\end{array}$ & $v \mathrm{C}=\mathrm{N}$ & $\begin{array}{c}\delta \mathrm{NH} \\
\text { Amide } \\
\text { II }\end{array}$ & $\begin{array}{c}\gamma \mathrm{NH} \\
\text { Amide } \\
\text { III }\end{array}$ & $\begin{array}{l}\beta \text { ring } \\
\text { pyridine } \\
\text { in plane }\end{array}$ & $v \mathrm{M}-\mathrm{N}$ \\
\hline INHDAB (HL) & - & 3053 & 1672 & 1590 & 1554 & 1331 & 604 & - \\
\hline$\left[\mathrm{Cu}(\mathrm{HL}) \mathrm{Cl}_{2}\right]$ & - & 3058 & 1660 & 1573 & 1551 & 1357 & 602 & 443 \\
\hline$\left[\mathrm{Ni}(\mathrm{HL}) \mathrm{Cl}_{2}\right] \cdot 2 \mathrm{H}_{2} \mathrm{O}$ & 3395 & 3059 & 1654 & 1577 & 1553 & 1354 & 597 & 419 \\
\hline$\left[\mathrm{Co}(\mathrm{HL})_{2} \mathrm{Cl}_{2}\right] \cdot 2 \mathrm{H}_{2} \mathrm{O}$ & 3358 & 3056 & 1655 & 1575 & 1550 & 1358 & 598 & 428 \\
\hline$\left[\mathrm{Mn}(\mathrm{HL})_{2} \mathrm{Cl}_{2}\right]$ & - & 3060 & 1657 & 1578 & 1549 & 1345 & 601 & 412 \\
\hline$\left[\mathrm{Cd}(\mathrm{HL}) \mathrm{Cl}_{2}\right]$ & - & 3091 & 1656 & 1574 & 1556 & 1352 & 605 & 421 \\
\hline
\end{tabular}

In the ligand spectrum $v \mathrm{NH}$ vibration from the imide group is located at $3053 \mathrm{~cm}^{-1}$. The amide band I is situated at $1672 \mathrm{~cm}^{-1}$ and the band at $1590 \mathrm{~cm}^{-1}$ is assigned to the vibration corresponding to the azomethine group ${ }^{16,17}$. The amide II $(\delta \mathrm{NH})$ and amide III $(\gamma \mathrm{NH})$ vibrations give bands in spectrum situated at $1554 \mathrm{~cm}^{-1}$ and $1331 \mathrm{~cm}^{-1}$ respectively. The weak band from $604 \mathrm{~cm}^{-1}$ shows the " $\beta$ " deformation in plane from the pyridinic ring. IR spectra of the complexes of $\mathrm{Ni}(\mathrm{II}), \mathrm{Co}(\mathrm{II})$ contain a broad band situated in the range 3400 $3350 \mathrm{~cm}^{-1}$; this band is associated to the lattice water from the composition of these complexes ${ }^{18}$. The imido $v \mathrm{NH}$ frequency appears in the region $3091-3056 \mathrm{~cm}^{-1}$ and as cosequence the imide group does not changed its structure during the coordination. The amide I vibration shift towards lower values and as a result the hydrazone ligand is 
coordinated to the metal ions by mean of the amide oxygen $(\mathrm{O}=\mathrm{C})^{19}$. The azomethine frequency band $v \mathrm{~N}=\mathrm{C}$ is found to the lower values suggests the azomethine nitrogen coordination in all the complexes ${ }^{20,21}$. The deformation in plane for the pyridinic ring is found at close values from that of free ligand and thus suggests that the nitrogen from the pyridinic ring is not involved in the coordination ${ }^{22}$. The coordination of the azomethine nitrogen of the INHDAB ligand to the $\mathrm{Cu}(\mathrm{II}), \mathrm{Ni}(\mathrm{II}), \mathrm{Co}(\mathrm{II}), \mathrm{Mn}(\mathrm{II}), \mathrm{Cd}$ (II) ions was also proved by the $v \mathrm{M}-\mathrm{N}$ vibrations appearing in the range $443-412 \mathrm{~cm}^{-1},{ }^{23}$ which were absent in the spectrum of the ligand.

\section{NMR spectra}

The INHDAB ligand formation is confirmed by the singlet from $\delta 8.40 \mathrm{ppm}$ assigned to the azomethine proton (-N=CH-) in ${ }^{1} \mathrm{H}$ NMR spectrum but also by the peak from $\delta 140.95 \mathrm{ppm}$ associated to the azomethine carbon in the ${ }^{13} \mathrm{C}$ NMR spectrum. Beside these values in the ${ }^{1} \mathrm{H}$ NMR spectrum of the ligand show signal to $\delta 11.97 ; \delta 8.78 \mathrm{ppm}$ assigned to the protons amide -NH-8; H-2,6 pyridine and also peaks in the ${ }^{13} \mathrm{C}$ NMR spectrum to $\delta 161.19 ; \delta 149.25$ ppm corresponding to the atoms of carbon amide-7; C-2,6 pyridine. In ${ }^{1} \mathrm{H}$ NMR spectrum of the complex of $\mathrm{Cd}(\mathrm{II})$ the signals of the protons $-\mathrm{NH}-8$ amide and azomethine shift with $0.34 \mathrm{ppm}$ and respectively $0.41 \mathrm{ppm}$ result which sustain the coordination of the ligand by the amide oxygen $\mathrm{O}=\mathrm{C}$ and the azomethine nitrogen. The signals of the atoms of carbon C-7 and C-10 in the ${ }^{13} \mathrm{C}$ NMR spectrum present shifts of $2.76 \mathrm{ppm}$ respectively $2.48 \mathrm{ppm}$ and pointed clearly the involvement of the atoms of amide oxygen and azomethine nitrogen in coordination. The atoms of carbon C-2,6 have signals in the same region of the spectrum and the shift is very small and in this way is confirmed that the pyridinic nitrogen is not involved in the coordination.

\section{Electronic spectra, ESR and magnetic determinations}

The electronic spectra (Table 3) and the magnetic moments support the stereochemistry of the complexes. The electronic spectrum of the INHDAB ligand presents a maximum of absorption at $28169 \mathrm{~cm}^{-1}$ assigned to the $\mathrm{n} \rightarrow \pi^{*}$ transition from the $\mathrm{C}=\mathrm{O}$ and $\mathrm{C}=\mathrm{N}$ chromophore groups. This transition could be found again in the complex combinations spectra but shifts towards lower frequencies, result which indicates the coordination of the ligand at the metallic ions ${ }^{24}$.

Table 3. Reflection spectra for the ligand and complexes.

\begin{tabular}{lcc}
\hline \multicolumn{1}{c}{ Compounds } & Frequencies, $\mathrm{cm}^{-1}$ & Assigning \\
\hline INHDAB $(\mathrm{HL})$ & 28169 & $\mathrm{n} \rightarrow \pi^{*}$ \\
& 26595 & $\mathrm{n} \rightarrow \pi^{*}$ \\
{$\left[\mathrm{Cu}(\mathrm{HL}) \mathrm{Cl}_{2}\right]$} & 19607 & ${ }^{2} \mathrm{~B}_{1 \mathrm{~g}} \rightarrow{ }^{2} \mathrm{E}_{\mathrm{g}}$ \\
& 14492 & ${ }^{2} \mathrm{~B}_{1 \mathrm{~g}} \rightarrow{ }^{2} \mathrm{~A}_{1 \mathrm{~g}}$ \\
{$\left[\mathrm{Ni}(\mathrm{HL}) \mathrm{Cl}_{2}\right] .2 \mathrm{H}_{2} \mathrm{O}$} & 27100 & $\mathrm{n} \rightarrow \pi^{*}$ \\
& 21834 & ${ }^{1} \mathrm{~A}_{1 \mathrm{~g}} \rightarrow{ }^{1} \mathrm{~B}_{1 \mathrm{~g}}$ \\
& 17605 & ${ }^{1} \mathrm{~A}_{1 \mathrm{~g}} \rightarrow{ }^{1} \mathrm{~A}_{2 \mathrm{~g}}$ \\
{$\left[\mathrm{Co}(\mathrm{HL})_{2} \mathrm{Cl}_{2}\right] .2 \mathrm{H}_{2} \mathrm{O}$} & 27472 & $\mathrm{n} \rightarrow \pi^{*}$ \\
& 19920 & ${ }^{4} \mathrm{~T}_{1 \mathrm{~g}} \rightarrow{ }^{4} \mathrm{~T}_{1 \mathrm{~g}}(\mathrm{P})$ \\
& 15137 & ${ }^{4} \mathrm{~T}_{1 \mathrm{~g}} \rightarrow{ }^{4} \mathrm{~A}_{2 \mathrm{~g}}(\mathrm{~F})$ \\
{$\left[\mathrm{Mn}(\mathrm{HL})_{2} \mathrm{Cl}_{2}\right]$} & 10224 & ${ }^{4} \mathrm{~T}_{1 \mathrm{~g}} \rightarrow{ }^{4} \mathrm{~T}_{2 \mathrm{gg}}(\mathrm{F})$ \\
& 27322 & $\mathrm{n} \rightarrow \pi^{*}$ \\
{$\left[\mathrm{Cd}(\mathrm{HL}) \mathrm{Cl}_{2}\right]$} & 24096 & $\mathrm{CT}$ \\
\hline
\end{tabular}


The $\mathrm{Cu}(\mathrm{II})$ complex displays electronic spectral bands in the region $19607 \mathrm{~cm}^{-1}$ and $14492 \mathrm{~cm}^{-1}$, which may be assigned to ${ }^{2} \mathrm{~B}_{1 \mathrm{~g}} \rightarrow{ }^{2} \mathrm{E}_{\mathrm{g}}$ and ${ }^{2} \mathrm{~B}_{1 \mathrm{~g}} \rightarrow{ }^{2} \mathrm{~A}_{1 \mathrm{~g}}$ transitions in a square-planar stereochemistry ${ }^{25}$. The experimental value of the magnetic moment is of 1.83 $\mathrm{BM}$ and suggests a monomeric square-planar geometry. The ESR spectrum of a polycrystalline sample of the complex measured at room temperature gave $\mathrm{g}_{\|}$and $\mathrm{g}_{\perp}$ values in the range of 2.164 and 2.073 , respectively. The high intensity of the signal confirms the monomeric molecular formula. The $\mathrm{g}_{\|}$and $\mathrm{g}_{\perp}$ values were $>2$, corresponding to an axial symmetry with all main axes disposed parallelly. The fact that $\mathrm{g}_{\|_{2}}>\mathrm{g}_{\perp}>2.0023$ supports a ground state of the $\mathrm{Cu}(\mathrm{II})$ ion with the unpaired electron in the $d_{x-y}^{2}{ }^{2}$ orbital and from the ESR spectrum there results an square-planar geometry ${ }^{26}$. The $\mathbf{G}$ parameter determined as $\mathrm{G}=\left[\left(\mathrm{g}_{\|}-2\right) /\left(\mathrm{g}_{\perp}-2\right)\right]$ was found to be much less than 4, suggesting considerable interaction in the solid state. For the Ni(II) complex, two absorption bands appeared at $17605 \mathrm{~cm}^{-1}$ and $21834 \mathrm{~cm}^{-1}$. These bands could be assigned to the transitions ${ }^{1} \mathrm{~A}_{1 \mathrm{~g}} \rightarrow{ }^{1} \mathrm{~A}_{2 \mathrm{~g}}$ and ${ }^{1} \mathrm{~A}_{1 \mathrm{~g}} \rightarrow{ }^{1} \mathrm{~B}_{1 \mathrm{~g}}$ which characterize the $\mathrm{Ni}$ (II) ion in the square-planar stereochemistry ${ }^{27}$. The diamagnetism of the complex confirms this symmetry. In the spectrum of Co(II) complex, the bands at $10224 \mathrm{~cm}^{-1}, 15137 \mathrm{~cm}^{-1}$ and $19920 \mathrm{~cm}^{-1}$ are associated to the transitions ${ }^{4} \mathrm{~T}_{1 \mathrm{~g}}(\mathrm{~F}) \rightarrow{ }^{4} \mathrm{~T}_{2 \mathrm{~g}}(\mathrm{~F})\left(v_{1}\right),{ }^{4} \mathrm{~T}_{1 \mathrm{~g}}(\mathrm{~F}) \rightarrow{ }^{4} \mathrm{~A}_{2 \mathrm{~g}}(\mathrm{~F})\left(\mathrm{v}_{2}\right)$ respectively ${ }^{4} \mathrm{~T}_{1 \mathrm{~g}}(\mathrm{~F}) \rightarrow{ }^{4} \mathrm{~T}_{1 \mathrm{~g}}$ (P) $\left(v_{3}\right)$. These transitions are specified to the $\mathrm{Co}(\mathrm{II})$ ion in the field of octahedral symmetry and the magnetic moment of $4.92 \mathrm{BM}$ corresponds to this geometry ${ }^{19}$. The ligand field splitting energy $(10 \mathrm{Dq})$, interelectronic repulsion parameter $(\mathrm{B})$ and nephelauxetic ratio $(\beta)$ for the $\mathrm{Co}$ (II) complex were calculated using the secular equations given by $\mathrm{König}^{28}$ and these correspond to the $10 \mathrm{Dq}=11388 \mathrm{~cm}^{-1}, \mathrm{~B}=724 \mathrm{~cm}^{-1}, \beta=0.74$ values.

$$
\begin{aligned}
10 \mathrm{Dq} & =2 v_{1}-v_{3}+15 \mathrm{~B} \\
\mathrm{~B} & =1 / 30\left[-\left(2 v_{1}-v_{3}\right)+\left(-v_{1}^{2}+v_{3}^{2}+v_{1} v_{3}\right)^{1 / 2}\right]
\end{aligned}
$$

The value of the $\beta$ parameter indicates a moderate covalent character for the metalligands bonds. In the case of the $\mathrm{Mn}(\mathrm{II})$ complex, the , $d-d$ ” transitions doubly forbidden from the fundamental term ${ }^{6} \mathrm{~A}_{1 \mathrm{~g}}$ towards the quartet terms ${ }^{4} \mathrm{~A}_{1 \mathrm{~g}}(\mathrm{G}),{ }^{4} \mathrm{E}_{\mathrm{g}}(\mathrm{G}),{ }^{4} \mathrm{~T}_{2 \mathrm{~g}}(\mathrm{G}),{ }^{4} \mathrm{~T}_{1 \mathrm{~g}}(\mathrm{G})$ exhibit a very small intensity and are concealed by the intraligand transitions ${ }^{29}$. The absorption band at $24096 \mathrm{~cm}^{-1}$ can be attributed to the charge transfer of ligand $\rightarrow$ metal. The magnetic moment of 5.86 BM supports an octahedral configuration of the type high spin around the $\mathrm{Mn}(\mathrm{II})$ ion. The $\mathrm{Cd}(\mathrm{II})$ complex presents an intense band situated at $25188 \mathrm{~cm}^{-1}$ which can be assigned to the charge transfer transition $\mathrm{L} \rightarrow \mathrm{M}^{30}$. The electronic spectroscopy doesn t permit the establish of a clear stereochemistry for the $\mathrm{Cd}(\mathrm{II})$ ion but taking into consideration the bidentate behaviour of the INHDAB (HL) ligand as well as the tendency of the $\mathrm{Cd}(\mathrm{II})$ ion for the tetrahedral geometry in the tetracoordination complexes, we propose this type of stereochemistry.

\section{Thermal analysis}

Thermal analysis by the TG and DTG techniques has proved to be very useful in determining the crystal water content in complexes and their thermal stability and decomposition mode under a controlled heating rate. The determined temperature ranges and the corresponding percent mass losses are given in Table 4 . For the complexes of $\mathrm{Ni}(\mathrm{II})$, $\mathrm{Co}$ (II) the lattice water is eliminated in the domain $85-155^{\circ} \mathrm{C}$. At high temperatures $\left(\mathrm{t}>240{ }^{\circ} \mathrm{C}\right)$ the complexes were decomposed and the INHDAB ligand was eliminated in two steps by oxidative degradations; in the final step $\left(\approx 700^{\circ} \mathrm{C}\right)$ results the metallic oxides as stable residue: $\mathrm{CuO}, \mathrm{NiO}, \mathrm{Co}_{3} \mathrm{O}_{4}, \mathrm{Mn}_{2} \mathrm{O}_{3}$ and $\mathrm{CdO}$. Data from the thermal analysis sustain the molecular formulas assigned for these complexes. The structural formulas assigned to the complexes are presented in Figure 2. 
Table 4. Thermal analysis for the complex combinations.

\begin{tabular}{|c|c|c|c|c|}
\hline \multirow[b]{2}{*}{ Complex } & \multicolumn{2}{|c|}{ Total mass losses } & \multirow[b]{2}{*}{$\underset{{ }^{\circ} \mathrm{C}}{\text { Temp. }}$} & \multirow[b]{2}{*}{$\begin{array}{c}\text { Loss, } \\
\%\end{array}$} \\
\hline & $\begin{array}{c}\text { Theoretical, } \\
\%\end{array}$ & $\begin{array}{c}\text { Experimental, } \\
\%\end{array}$ & & \\
\hline \multirow{4}{*}[\mathrm{Cu}(\mathrm{HL})\mathrm{Cl}_{2}]{} & \multirow{4}{*}{85.32} & \multirow{4}{*}{84.94} & $240-395$ & 32.24 \\
\hline & & & $395-650$ & 52.70 \\
\hline & & & $650-700$ & 14.88 exp./res. \\
\hline & & & & 15.10 calc./res. \\
\hline \multirow{4}{*}[\mathrm{Ni}(\mathrm{HL})\mathrm{Cl}_{2}]{$\cdot 2 \mathrm{H}_{2} \mathrm{O}$} & \multirow{4}{*}{87.06} & \multirow{4}{*}{86.61} & $85-145$ & 6.28 \\
\hline & & & $145-470$ & 53.92 \\
\hline & & & $470-640$ & 26.41 \\
\hline & & & $640-700$ & $\begin{array}{l}13.18 \text { exp./res. } \\
13.39 \text { calc./res. }\end{array}$ \\
\hline \multirow{4}{*}[\mathrm{Co}(\mathrm{HL})_{2}\mathrm{Cl}_{2}]{$\cdot 2 \mathrm{H}_{2} \mathrm{O}$} & \multirow{4}{*}{91.89} & \multirow{4}{*}{91.56} & $90-155$ & 3.61 \\
\hline & & & $155-430$ & 41.27 \\
\hline & & & $430-665$ & 46.68 \\
\hline & & & $665-700$ & $\begin{array}{l}8.25 \text { exp./res. } \\
8.44 \text { calc./res. }\end{array}$ \\
\hline \multirow{3}{*}[\mathrm{Mn}(\mathrm{HL})_{2}\mathrm{Cl}_{2}]{} & \multirow{3}{*}{91.67} & \multirow{3}{*}{91.33} & $245-440$ & 22.36 \\
\hline & & & $440-670$ & 68.97 \\
\hline & & & $670-700$ & $\begin{array}{l}8.46 \text { exp./res. } \\
8.67 \text { calc./res. }\end{array}$ \\
\hline \multirow{3}{*}[\mathrm{Cd}(\mathrm{HL})\mathrm{Cl}_{2}]{} & \multirow{3}{*}{77.98} & \multirow{3}{*}{77.75} & $260-465$ & 17.03 \\
\hline & & & $465-660$ & 60.72 \\
\hline & & & $660-700$ & $\begin{array}{l}22.09 \text { exp./res. } \\
22.31 \text { calc./res. }\end{array}$ \\
\hline
\end{tabular}

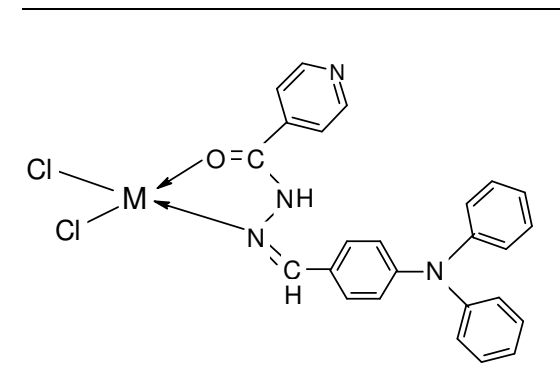

(a)

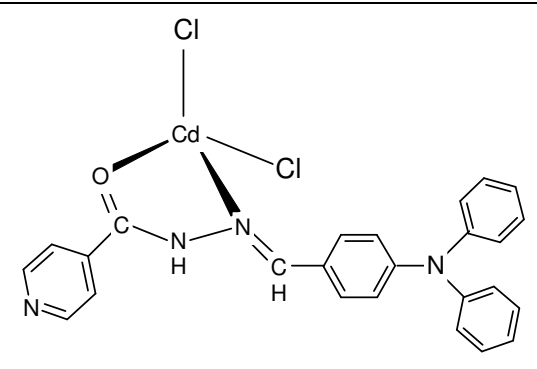

(b)

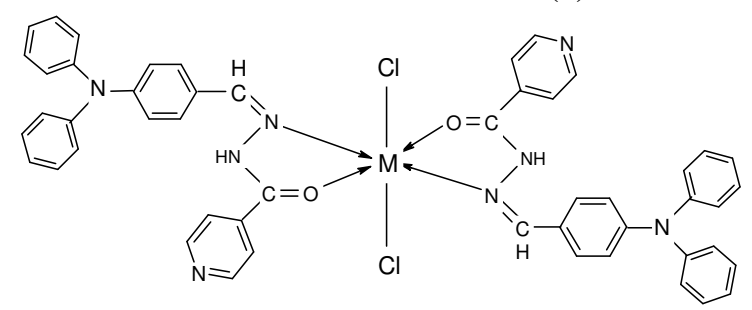

(c)

Figure 2. The structural formula of the complexes; (a) $\left[\mathrm{M}(\mathrm{INHDAB}) \mathrm{Cl}_{2}\right] \cdot \mathrm{xH}_{2} \mathrm{O} ; \mathrm{M}=$ $\mathrm{Cu}(\mathrm{II}) \mathrm{x}=0 ; \mathrm{M}=\mathrm{Ni}(\mathrm{II}) \mathrm{x}=2$; (b) $\left[\mathrm{Cd}(\mathrm{INHDAB}) \mathrm{Cl}_{2}\right]$; (c) $\left[\mathrm{M}(\mathrm{INHDAB})_{2} \mathrm{Cl}_{2}\right] \cdot \mathrm{xH}_{2} \mathrm{O} ; \mathrm{M}=$ $\operatorname{Co}($ II) $\mathrm{x}=2 ; \mathrm{M}=\mathrm{Mn}(\mathrm{II}) \mathrm{x}=0$ 


\section{Antimicrobial activity}

The antimicrobial activity of the synthetized complexes and INHDAB ligand it was evaluated on the gram-(+) bacteria Staphylococcus aureus and on the gram-(-) bacteria Escherichia coli, Pseudomonas aeruginosa, Salmonella enteritidis and Shigella flexneri. Table 5 shows the obtained results expressed by the diameter of the inhibition zone of the growth bacteria by the tested compounds.

Table 5. Antimicrobial activity of INHDAB and its metal complexes.

\begin{tabular}{|c|c|c|c|c|c|}
\hline \multirow[b]{2}{*}{ Compound } & \multicolumn{5}{|c|}{ Bacteria / Inhibition zone (mm) } \\
\hline & $\begin{array}{c}\text { S. aureus } \\
\text { gram-(+) } \\
\text { ATCC } \\
25923\end{array}$ & $\begin{array}{c}\text { E. coli } \\
\text { gram-(-) } \\
\text { ATCC } \\
25922\end{array}$ & $\begin{array}{c}\text { P. aeruginosa } \\
\text { gram-(-) } \\
\text { ATCC } \\
27853\end{array}$ & $\begin{array}{c}\text { S. enteritidis } \\
\text { gram-(-) } \\
\text { Code } \\
10871\end{array}$ & $\begin{array}{l}\text { S. flexneri } \\
\text { gram-(-) } \\
\text { Code } \\
13532\end{array}$ \\
\hline INHDAB (HL) & 4 & 5 & 5 & 5 & 4 \\
\hline$\left[\mathrm{Cu}(\mathrm{HL}) \mathrm{Cl}_{2}\right]$ & 5 & 4 & 4 & 4 & 5 \\
\hline$\left[\mathrm{Ni}(\mathrm{HL}) \mathrm{Cl}_{2}\right] \cdot 2 \mathrm{H}_{2} \mathrm{O}$ & 10 & 12 & 11 & 10 & 9 \\
\hline$\left[\mathrm{Co}(\mathrm{HL})_{2} \mathrm{Cl}_{2}\right] \cdot 2 \mathrm{H}_{2} \mathrm{O}$ & 6 & 5 & 6 & 6 & 4 \\
\hline$\left[\mathrm{Mn}(\mathrm{HL})_{2} \mathrm{Cl}_{2}\right]$ & 11 & 4 & 10 & 5 & 12 \\
\hline$\left[\mathrm{Cd}(\mathrm{HL}) \mathrm{Cl}_{2}\right]$ & 16 & 18 & 19 & 6 & 7 \\
\hline Ciprofloxacin & 25 & 30 & 24 & 28 & 31 \\
\hline
\end{tabular}

The results show that INHDAB exhibited weak activity. The complexes of $\mathrm{Cu}(\mathrm{II})$, $\mathrm{Co}$ (II) show a weak action compared to all the germs and the complexes of $\mathrm{Ni}(\mathrm{II}), \mathrm{Mn}$ (II) are a little more active compared to Staphylococcus aureus, Pseudomonas aeruginosa and Shigella flexneri. The Cd(II) complex manifest maximum activity to Staphylococcus aureus, Escherichia coli, Pseudomonas aeruginosa and this effect is assigned to the donor atoms which are not involved in the coordination but become more active by the formation of the complex combination ${ }^{20}$. The increased activity of the chelates can be explained based on the overtone concept and the Tweedy chelation theory ${ }^{31}$. According to the overtone concept of cell permeability, the lipid membrane surrounding the cell favours the passage of only lipid-soluble materials, which means that liposolubility is an important factor controlling antimicrobial activity. On chelation, the polarity of metal ion is reduced to a greater extent due to overlap of the ligand orbital and partial sharing of its positive charge with the donor groups. In addition, it is also due to delocalization of the $\pi$-electrons over whole chelate ring, enhancing the penetration of the complexes into the lipid membranes and the blocking of the metal binding sites of the enzymes of the microorganisms.

\section{References}

1. Al-Hokbany N S and Mahfouz R M, J Saudi Chem Soc., 2010, 14(4), 391.

2. Sharma R N, Sharma K P and Dixit S N, Oriental J Chem., 2010, 26(1), 69.

3. Tenchiu A C, Iliş M, Dumitraşcu F, Whitwood A C and Cîrcu V, Polyhedron, 2008, 27, 3537.

4. Fabin M and Palmer G, Biochemistry, 2001, 40, 40.

5. Khalil M M H and Al-Seif F A, J Saudi Chem Soc., 2010, 14(1), 33.

6. Sharma N K, Agarwal M, Kohli S, Tiwari B and Agarwal B, Oriental $J$ Chem., 2010, 26(1), 103.

7. Mocanu A S, Iliş M, Dumitraşcu F, Ilie M and Cîrcu V, Inorganica Chim Acta, 2010, 363, 729. 
8. Dhingra S, Srivastava A K and Dhingra V, J Saudi Chem Soc., 2010, 14(2), 213.

9. Sharma R N, Sharma K P and Taigar R L, Oriental J Chem., 2010, 26(1), 181.

10. Budhani P, Iqbal S A, Bhattacharya S M M and Mitu L, J Saudi Chem Soc., 2010, 14(3), 281.

11. Naik C G and Malik G M, Oriental J Chem., 2010, 26(1), 211.

12. Cîrcu V, Mănăilă D, Roşu C, Iliş M, Molard Y and Dumitraşcu F, Liquid Cryst., 2009, 36(2), 123.

13. Mitu L, Farook Mohamed N A, Iqbal S A, Raman N, Imran M and Sharma S K, E-J Chem., 2010, 7(1), 227.

14. Mitu L, Raman N, Kriza A, Stănică N and Dianu M, J Serb Chem Soc., 2009, 74(10), 1075.

15. Macarovici C G, Analiza Chimică Cantitativă Anorganică (Inorganic Quantitative Chemical Analysis); Editura Academiei R S R, Bucureşti, 1979.

16. Malik V, Solanki G and Singh V, Oriental J Chem., 2010, 26(1), 301.

17. Bakkar M, Monshi M, Warad I, Siddiqui M and Bahajaj A, J Saudi Chem Soc., 2010, 14(2), 165.

18. Nazir M and Naqvi I I, J Saudi Chem Soc., 2010, 14(1), 101.

19. Mitu L, Raman N, Kriza A, Stănică N and Dianu M, Asian J Chem., 2009, 21(7), 5749.

20. Sharma S, Iqbal S A and Budhani P, Oriental J Chem., 2010, 26(1), 297.

21. Cî̀ru V, Iliş M and Dumitraşcu F, J Optoelectr Advanced Mater., 2008, 10(12), 3454.

22. Agarwala B V, Acta Chim Hungarica, 1990, 102, 269.

23. Peizhi C L, Xiaolan D and Boz, Asian J Chem., 2005, 17, 969.

24. Ghose B N and Lasisi K M, Synth React Inorg Met-Org Chem., 1986, 16, 1121.

25. Raman N, Mitu L, Sakthivel A and Pandi M S S, J Iran Chem Soc., 2009, 6(4), 738.

26. Raman N, Jeyamurugan R, Rani R U, Baskaran T and Mitu L, J Coord Chem., 2010, 63(9), 1629.

27. Raman N, Jeyamurugan R, Sakthivel A and Mitu L, Spectrochimica Acta Part A: Mol and Biomol Spectros., 2010, 75(1), 88.

28. König E, Struct Bond., 1971, 9, 175.

29. Lever A B P, Inorganic Electronic Spectroscopy; Elsevier, London, 1968.

30. Mitu L, Kriza A and Dianu M, Asian J Chem., 2008, 20(2), 1627.

31. Raman N, Kulandaisamy A and Tungaraja C, Transition Metal Chem., 2004, 29, 129. 


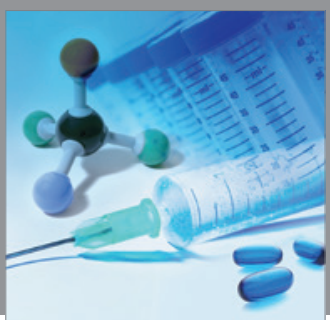

International Journal of

Medicinal Chemistry

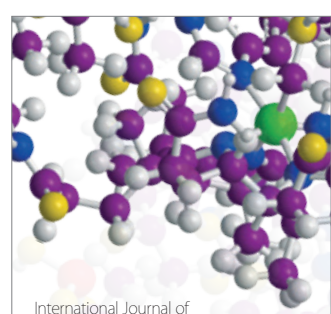

Carbohydrate Chemistry

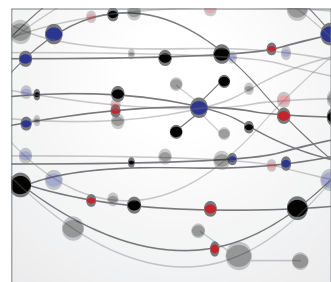

The Scientific World Journal
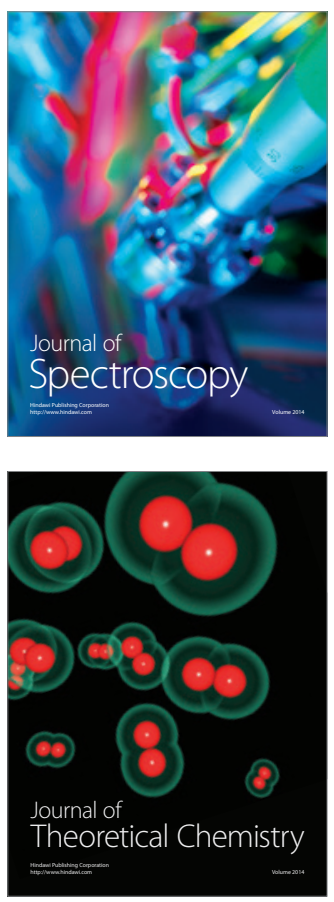
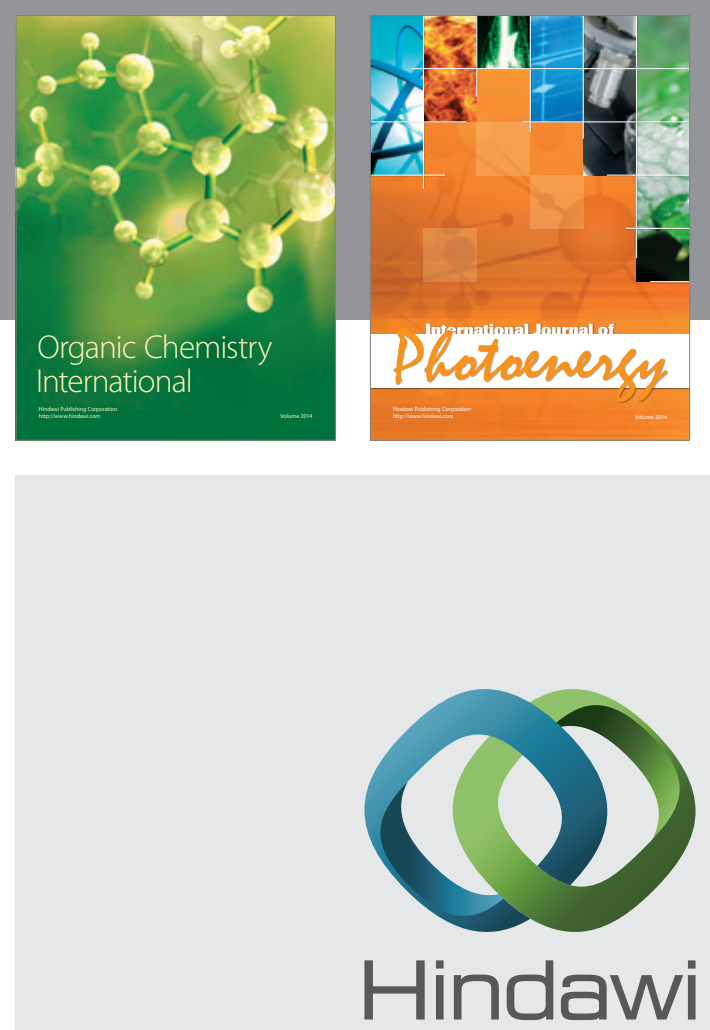

Submit your manuscripts at

http://www.hindawi.com
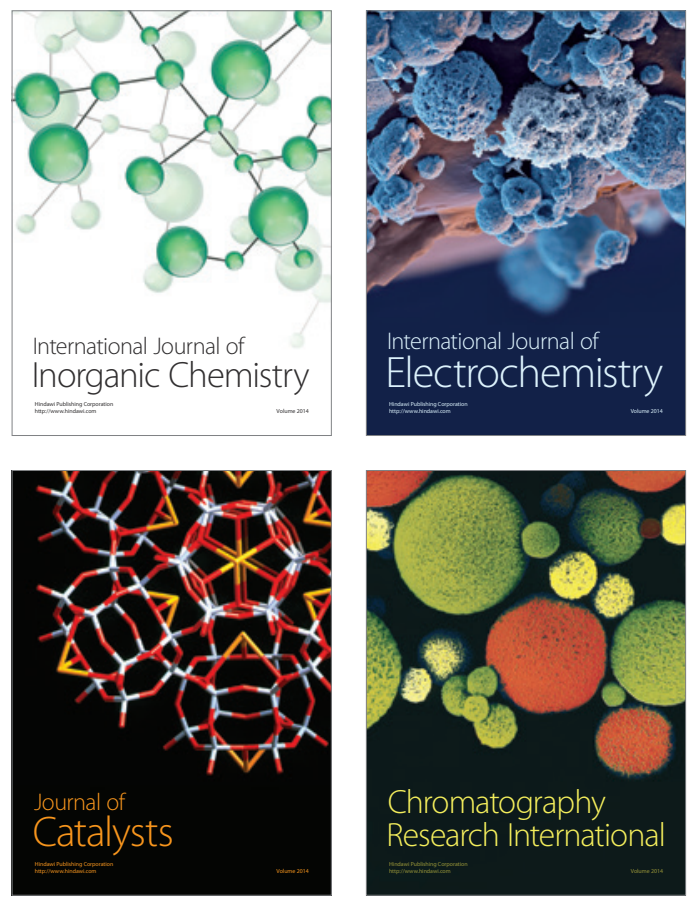
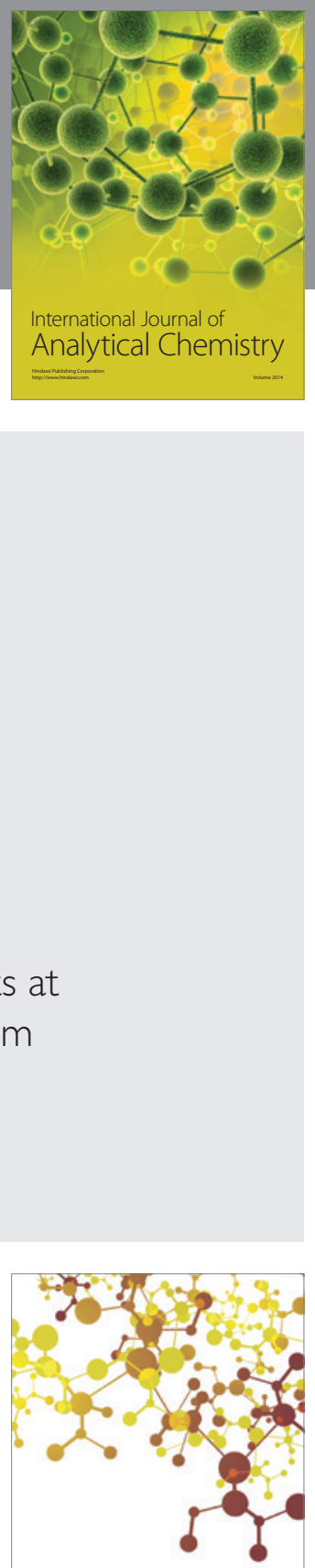

Journal of

Applied Chemistry
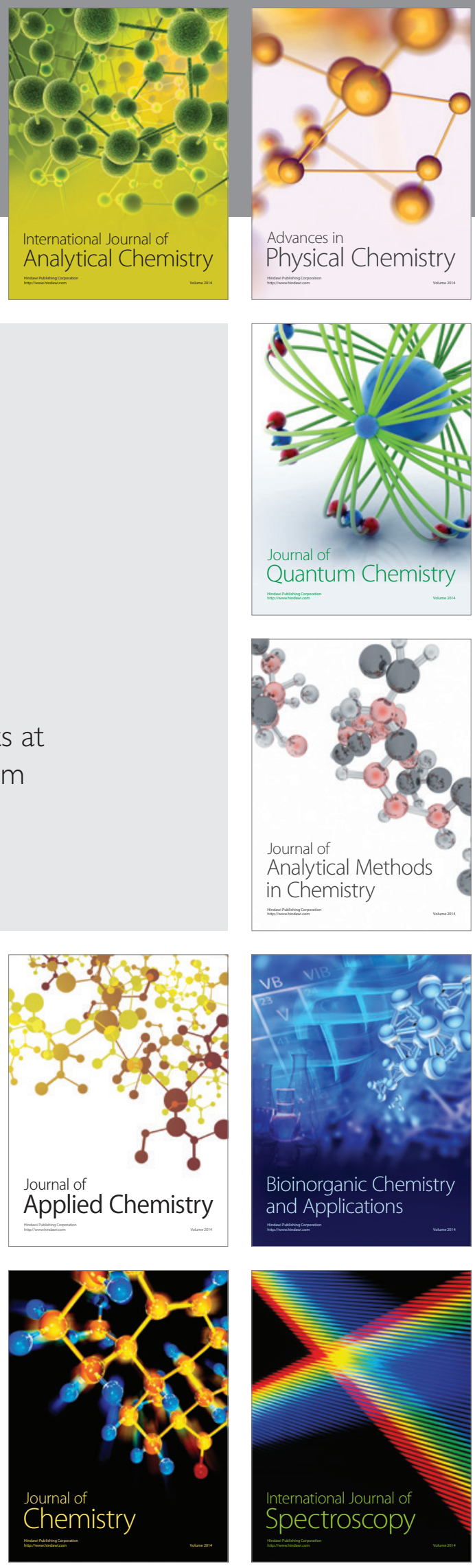